\title{
Comparison of dispute boards and statutory adjudication in construction
}

Robert Lopez Dip (BD\&D), BAppSc (CM\&E) Hon, PhD (CM) Research Associate, School of Design and the Built Environment, Curtin University, Perth, Australia (corresponding author: r.lopez@curtin.edu.au)
Alberto Amara Dip (B\&C-B), BAppSc (CM) Hon

Operations Director, Collier Homes (1959) Pty Ltd, Perth, Australia

The objective of this study is to present the issues encountered by construction industry practitioners resolving disputes through the adoption of the dispute board (or DB) and statutory adjudication (or SA). This research is significant due to the often adversarial working environment in a typical construction and engineering project, as well as substantial adverse consequences resulting from disputes that have not been adequately resolved between two or more of its stakeholders. This paper presents the historical background and aims of and main principles behind the introduction of DB and SA. Stakeholder practitioners involved in three case study projects were then interviewed to reveal issues encountered with their adoption of DBs and/or SAs. Their perceived effectiveness, as well as suitability, to resolve disputes within construction then underwent comparative analysis. Barriers were found which had contributed towards a general apprehension by practitioners in the major case study projects to adopt either of these dispute-resolution methods. This paper suggests that these barriers significantly relate to the perceived formality of their procedures, potentially expensive legal costs involved and subsequent harm to future working relationships.

\section{Introduction}

Construction and engineering projects by their nature are heavily dependent on subcontracted work (ABS, 2017; Cole, 2003; Davenport, 2010; Yung and Rafferty, 2014). The contractor could abuse their capability of shifting risks away from themselves by delaying or reducing payments from those amounts otherwise due to their subcontractors (Brand and Davenport, 2012; Wong et al., 2015; Yung and Rafferty, 2014). A focus on the prevention of disputes is rare (Murphy et al., 2014). Disputes could potentially result in cost increases, delays and deteriorated working relationships (Chapman, 2009; Gebken-Li and Gibson, 2006; Harmon, 2003a). Resolving these quickly could serve to prevent further disputes and minimise their associated cost (Davenport, 2010; Murphy et al., 2014).

Two prominent methods used for resolving disputes include the dispute board (or DB) and statutory adjudication (or SA) (Gebken-Li and Gibson, 2006; Murphy et al., 2014), which, in New South Wales, Australia, are conducted in compliance with the Building and Construction Industry Security of Payment Act 1999 (NSW Government, 1999), known as the SoP Act. DBs in particular focus on dispute prevention and should be used in conjunction with another method for resolving disputes (DRBF, 2016; Harmon, 2003a; Yates and Duran, 2006). Both the DB and SA have been proven by Harmon (2003a, 2003b) as effective in contributing towards the productivity of construction and engineering projects. Previously, Harmon (2003a) has reviewed a range of conventional dispute-resolution methods used in construction. Gebken-Li and Gibson (2006) have quantified their costs. Chapman (2009) had studied the use of DB in major construction projects. The research work presented in this paper departs from these studies as it focused on comparing the unconventional alternate methods of dispute resolution (or ADR), DB and SA.
This research examined DB and SA by comparing how these two methods have been employed, as well as utilised, within case study construction projects. It also examined the issues encountered by construction industry practitioners in resolving disputes by adopting and using both of these methods. Perceptions of their effectiveness/ineffectiveness and suitability/ unsuitability as methods of dispute resolution are highlighted. While Yung and Rafferty (2014) recently examined the viewpoints of adjudicators, those of other construction industry practitioners have generally remained not investigated. The aim of the research presented in this paper was therefore to evaluate the present understanding and experiences of industry practitioners on DBs and SAs. To address this aim, the research comprised the following objectives.

- Establish whether the need exists for ADR in a construction and engineering project.

- Determine perceived barriers in DB implementation on a construction and engineering project.

- Explore SA experiences and perceptions of its effectiveness in a construction and engineering project.

\section{Dispute boards}

DBs have been included in standard forms of construction contracts prepared by the International Federation of Consulting Engineers and International Chamber of Commerce - World Business Organization (Fidic, 2017; ICC-WBO, 2017). It is also required as a fundamental part of the construction project financial arrangements of many agencies including the World Bank (2017).

\subsection{Dispute boards history, principles and focus}

Understanding that a focus on avoidance will help reduce disputes and in turn curtail the need for methods to resolve them, there has 
recently been a movement within the UK construction industry on 'getting it right the first time' (Partington, 2017: p. 179). The focus of this industry movement has generally been on ensuring due diligence when contracting and subcontracting, avoiding circumvention and setting in place effective methods for dispute resolution. The latter implicitly recognises that disputes in construction still remain inevitable (Drake Quantity Surveying, 2013; Salmon, 2015). This movement is certainly not without precedent, particularly as it was with a similar focus that the DB was introduced as a construction dispute avoidance and resolution method in the USA during the 1970s (Chapman, 2009; Harmon, 2003b).

Harmon (2012) reported that DBs have been used in 2340 construction and engineering projects internationally between 1974 and 2012, amounting to a combined industry cost of approximately US $\$ 175 \cdot 5$ billion (XE.com, 2017). Each DB often comprises a panel of three construction professionals (Agdas and Ellis, 2013; CIArb-Australia, 2016; Harmon, 2003b). A DB could be arranged as standing or ad hoc under either of the guises presented in Table 1 (CIArb-Australia, 2016). When compared with SAs, DBs have the following benefits (DRBF, 2016).

- Panel members are respected as they are selected by each party based on reputation and expertise, whereas adjudicators are normally unknown to the parties involved.

- DB is involved from the beginning of the construction/ engineering project, whereas adjudicators normally have no prior involvement or knowledge with either party.

- Identifying and discussing possible problems with the reporting procedure are actually encouraged at DB meetings that are held routinely.

\subsection{Dispute boards' perceived effectiveness}

The Cooperative Research Centre (CRC)-Construction Innovation (2009), in their research on dispute avoidance and resolution, found that $97 \%$ of DB decisions have been either accepted or de-escalated down to settlement negotiations. In addition, the cost of settling disputes using a DB is estimated at approximately $0.3 \%$ of a construction/engineering project's contract sum (Agdas and Ellis, 2013). Similar benefits of DBs were previously found by Yates and Duran (2006), who demonstrated their effectiveness in preventing litigation on a tunnel engineering project case study. The effectiveness of DBs was previously surveyed by Harmon (2003b), in her survey of 48 construction professionals. She found that $100 \%$ of these survey participants believed that DBs contribute towards project productivity, with reports of positive (or + ) outcomes from its use by approximately $87 \%$ of them (Harmon, 2003b).

Harmon (2009) also researched the effectiveness of the DB within a megaproject in the USA. Megaprojects have been defined by the Federal Highway Administration as 'major infrastructure projects that cost more than [USD] \$1 billion ... that attract a high level of public attention or political interest because of substantial direct and indirect impacts on the community' (FHWA, 2017: p.1). The identified barriers to the effectiveness of a DB were its adversarial perception, lengthy procedures, unconvincing outcomes and fewer disputes resolved than expected (Harmon, 2009). Harmon (2012), from her review of 2753 disputes presented to DBs in construction projects, also reported the following.

Eighty-eight per cent of these (or 2426) reached a satisfactory resolution.

- Twelve per cent of these (or 327) continued onto another method of dispute resolution.

- Significant cost and time benefits were encountered.

- The value of DBs has been recognised through their increased use.

\section{Statutory adjudication}

Love et al. (2011), in referring to dispute causes as pathogens, found that a significant proportion of them were caused either by circumstances, malpractices, performances or any of these combined. They have also determined the majority of construction disputes that were settled through the use of SA in particular, as an ADR method actually concerns issues with the conventional legal 'civil procedure' in place (Love et al., 2010: p. 421).

\subsection{Statutory adjudication's perceived effectiveness}

When compared with arbitration/litigation, SoP legislation could resolve payment disputes significantly quicker (Wong et al., 2015). The reported effectiveness of each jurisdiction in addressing problems of SoP varies (Brand and Davenport, 2011; Ross, 2013). Yung and Rafferty (2014) evaluated how effective the Construction Contracts Act 2004 (Government of Western Australia, 2004) is at its stipulated focus from a survey of 22 adjudicators. Their main findings on SA relative to other methods were as follows (Yung and Rafferty, 2014).

- SA is less effective for smaller than larger cost claims.

- SA has a lower rate of appeal, indicating that more of its dismissal decisions are fair.

Table 1. Dispute board guises

\begin{tabular}{lcl} 
DB guise & Acronym & \multicolumn{1}{c}{ Description } \\
\hline Dispute adjudication board & DAB & Adjudicates disputes between parties and makes binding determinations \\
Dispute review board & DRB & $\begin{array}{l}\text { Analyses disputes between parties and makes non-binding recommendations } \\
\text { Combined dispute board }\end{array}$ \\
CDB & $\begin{array}{l}\text { Analyses disputes between parties and either makes binding determinations or non-binding } \\
\text { recommendations }\end{array}$
\end{tabular}


- SA is generally becoming more popular by virtue of an increase in its uptake.

Approaches towards SA are generally inconsistent and vary significantly between jurisdictions (Brand and Davenport, 2011). Such inconsistencies are problematic in disputes between geographically dispersed parties across jurisdictions, each of which have been advised not to depend on determinations made at another jurisdiction (Ross, 2013). Brand and Davenport (2012), from their research of the amended SoP Act (NSW Government, 2010), found courts to permit the inclusion of costs for delays and damages within construction progress claims. They also found that after using SAs, parties will rarely then also pursue arbitration/litigation (Brand and Davenport, 2011). Skaik et al. (2016) recently reviewed various law cases, commentaries and government reports on the inconsistencies associated with SoP legislation, as well as their impact on the construction industry. The frequent rate of adjudication errors in disputes could potentially escalate many of these into arbitration/litigation (Skaik et al., 2016).

\section{Dispute board and statutory adjudication compatibility}

With SA being used in construction and engineering projects, the $\mathrm{DB}$ is normally regarded as either useless or incompatible. Experiences have been contrary to this viewpoint (DRBF, 2016). The first consideration is whether the DB could adjudicate in accordance with SoP legislation. The second is whether a DB determination of any payment dispute will be binding and represent a substitute of SA. The Construction Contracts Act 2004 (Government of Western Australia, 2004) explicitly mentions the following (clauses 28.1.a and 53.1).

- Applications for SA are to be served onto the person who appoints an adjudicator.

- Parties of a dispute are unable to prevent SA through any contract provisions.

Where parties have adopted a DB, they typically allow it to make binding and final determinations on every payment dispute (DRBF, 2016; Harmon, 2012). Despite their shortcomings, the use of DBs has generally been effective worldwide (Harmon, 2012). In particular, New Zealand, Singapore and UK jurisdictions have SoP legislations that are similar to each other (Yung and Rafferty, 2014). This could be the result of the practical financial considerations of parties taking precedence over their perceived legal technicalities (DRBF, 2016).

Cheung (1999), during his research on ADR processes, found that an adjunct neutral DB will procedurally become involved when there is a failure to negotiate. He also found SA to be an alternative procedural option when a dispute develops (Cheung, 1999). The theory of procedure is defined by Thibaut and Walker (1978: p. 541) as 'the necessary result of differences in the type of conflict involved in the dispute'. The following types and features of conflict have previously been identified from their theory of procedure (Thibaut and Walker, 1978)

- low cognitive and high interest conflict - justice dominates truth

- high cognitive and low interest conflict - truth dominates justice

- high cognitive and high interest conflict - equal mix of justice and truth.

Thibaut and Walker (1978: p. 542) define justice as 'when the ultimate outcomes are distributed to contending parties in proportion to their respective contributions or inputs to the transaction underlying the dispute'. They argued that justice will most likely come from a process which allows for many inputs to be reported before making a determination (Thibaut and Walker, 1978). Truth is defined by Thibaut and Walker (1978: p. 541) as 'the most accurate view of reality'. They also recommended an autocratic process for determining truth (Thibaut and Walker, 1978).

Aibinu et al. (2006, 2008, 2011) have more recently applied this theory of procedure to the construction context in their research on relationships between distributions of control fairness and likelihood of dispute from handling claims for payment. The theory of transaction cost economics is generally defined by Williamson (1979: p. 6) as 'issues relating to the organisation of work'. Hierarchical transactions normally take place within construction projects, and issues with such arrangements could include strategic behaviour to engage in predatory pricing (Williamson, 1975, 1979, 1980). The data analyses and discussion of findings are informed by these theories in order to provide insight into how the features of DB and SA influence conflicts to be resolved, their outcomes and views of parties involved, on the construction project cases studied.

\section{Research methodology}

An approach based on the gathering of qualitative data was deemed suited to the objectives of the research presented in this paper as they focus on the current understanding, as well as experiences, of SAs and DBs. A descriptive and applied case study approach was therefore the adopted framework for the field study. Case studies are justifiably a better approach for this kind of research topic because of their potential to provide deeper insight than a survey. The selection of the three cases was carefully done based on the fact that DB and SA were used on these projects. Only major projects that match the research objectives were considered in case selection. Figure 1 illustrates that the methods facilitating this research are composed of the following

- a review of literature

- semistructured interviews

case study-based investigation.

\subsection{Sampling}

Identifying and selecting the research sample was critical (Robson, 2011). This is because their selection should suit, or at 
Comparison of dispute boards and statutory adjudication in construction Lopez and Amara

\begin{tabular}{|c|c|c|}
\hline \multirow{9}{*}{$\begin{array}{l}\text { Review of } \\
\text { relevant } \\
\text { literature }\end{array}$} & \multirow{4}{*}{ - $\mathrm{DB}$} & - DB history \\
\hline & & - DB principles \\
\hline & & - DB focus \\
\hline & & - DB perceived effectiveness \\
\hline & \multirow{4}{*}{ - SA } & - SA history \\
\hline & & - SA principles \\
\hline & & - SA focus \\
\hline & & - SA perceived effectiveness \\
\hline & \multicolumn{2}{|c|}{ - DB and SA compatibility } \\
\hline
\end{tabular}

\begin{tabular}{|l|l|}
\hline \multirow{4}{*}{ Field research methodology } & $\bullet$ sampling \\
\cline { 2 - 3 } & $\bullet$ respondent profiles \\
\cline { 2 - 2 } & $\bullet$ structured interviews \\
\hline & $\bullet$ qualitative data \\
\hline
\end{tabular}

\begin{tabular}{|c|c|c|}
\hline \multirow{7}{*}{$\begin{array}{l}\text { Case } \\
\text { study } \\
\text { projects }\end{array}$} & \multicolumn{2}{|c|}{ - stakeholder interactivity } \\
\hline & \multirow{3}{*}{$\begin{array}{l}\text { - } \text { DB } \\
\text { situations }\end{array}$} & - DB barriers \\
\hline & & - DB standardisation \\
\hline & & - DB effectiveness \\
\hline & \multirow{3}{*}{$\begin{array}{l}\text { - SA } \\
\text { situations }\end{array}$} & - SA requirements \\
\hline & & - SA objectives \\
\hline & & - SA effectiveness \\
\hline
\end{tabular}

\begin{tabular}{|l|l|}
\hline \multirow{2}{*}{$\begin{array}{l}\text { Discussion of } \\
\text { findings and } \\
\text { recommendations }\end{array}$} & $\bullet$ addressing the research objectives \\
\cline { 2 - 2 } & $\bullet$ value of research \\
\cline { 2 - 2 } & $\bullet$ recommendations \\
\hline
\end{tabular}

Figure 1. Configuration of research

least relate to, the context of this research (Hall, 2008). The research sample needed to be selected partially based on their exposure to both of these ADR methods. Research sample exclusions/inclusions were also determined base on their roles and involvement within the construction/engineering project case studies. Each of them was required to have direct or indirect involvement with these case study projects. In addition to this was the requirement for a diverse range of roles that achieve a breadth of industry representation. Research participants were sourced through the snowballing of the researchers' networks employed within construction, combined with searches of LinkedIn (2017) for additional industry practitioners with suitable profiles.

\subsection{Respondent profiles}

Industry practitioners who were selected by virtue of their experiences with dispute resolution encompass adjudicators, contractors, engineers, lawyers, quantity surveyors and subcontractors. Particularly valuable sources of data were those who also had a background in the legal industry, primarily due to their strength of understanding project outcomes and reasoning. Over a hundred construction industry practitioners were invited to partake in this research by way of email. Each email contained some background information on the research presented in this paper, the questions and a consent form for them to complete and return. Of those invited, a total of 33 construction industry practitioners returned this consent form completed, which represents an acceptable rate of response in field research (Fellows and Liu, 2008).

\subsection{Semistructured interviews}

A semistructured research instrument of closed and open questions was used for the interviews. It has been developed with questions that encouraged the expression of opinions and attitudes by interviewees. These questions were informed by the review of relevant literature, but appropriately arranged in a strategy to clarify context and improve the accuracy of answers. The suitability of the adopted research framework was justified as it enabled the diversity of industry experiences and knowledge to be made available from interviewing a variety of case study project stakeholders (Robson, 2011). Towards this end, the following questions had been asked of all research participants.

— 'Have you ever been involved with statutory adjudication?'

- 'In your opinion, was statutory adjudication effective both in cost and in resolving disputation? Can you provide examples as to why?'

- 'As you see it, what is the objective/s of statutory adjudication? Do you believe that this objective/s is being achieved? Can you provide some examples as to why?'

- 'Do you believe that there is a need for alternate dispute resolution in the construction industry?'

- 'Have you ever been involved with a project that had adopted the use of a dispute board? Which form of dispute board was it?'

- 'In your opinion, was the dispute board approach effective both in cost and in reducing or avoiding disputation?'

- 'Should a dispute board become the norm for contracts of a particular size or nature?'

- 'Barrier/s towards adopting a dispute board?'

\subsection{Qualitative data}

When the qualitative raw data were gathered, the interview recordings were transcribed. After this, relevant quotations from these transcripts were analysed using NVivo software, where they are organised into nodes that resembled the primary themes of the three case study projects (QSR International, 2017). The openended nature of the semistructured research instrument used in the interviews facilitated the consistency of themes identified, without the need for asking probing questions. These themes naturally 
reflect the commonalities identified from the organised raw data. A comparison between findings from the case studies and the review of relevant literature was then made. Both contradictory and corroboratory findings were yielded from the research presented in this paper as the result.

\subsection{Case study particulars}

Case study A involved design, construction and demolition work at an existing correctional facility. Stage 1 involved designing and constructing a new correctional building composed of over 300 beds. Then, stage 2 involved carefully demolishing the existing correctional building alongside it. Case study A encountered a variety of delays from the constraints of a tight schedule, logistics and disputes.

Case study B involved designing and constructing a healthcare facility with four ten-storey interconnected blocks comprising over 250 beds, all above a basement floor level. A number of construction delays and disputes were encountered in case study B. Representatives of the architect and lawyers involved believed that stakeholder interactions are normally harmonious outside from government-procured projects such as case study B, which encountered threats, contractual variation claims and disputes.

Case study C was an engineering infrastructure development comprising a liquefied natural gas (or LNG) plant and subsea fields. The lawyer involved believed that stakeholder interactions on this project were not harmonious. Significant construction cost blowouts, delays and disputes were encountered in case study $\mathrm{C}$.

\section{Comparative analysis and results}

In case studies $\mathrm{A}$ and $\mathrm{B}$, there was a greater prevalence of the use of SA than DB. This infers that stakeholders in these projects were often willing to continue negotiating resolutions for their disputes amicably without pursuing the formal civil procedures set (Cheung, 1999; Love et al., 2010). In contrast to case studies $\mathrm{A}$ and $\mathrm{B}$, there was a greater prevalence of the use of DB than SA in case study C. This infers that stakeholders in case study $\mathrm{C}$ often could not negotiate resolutions for their disputes and were more willing to engage the services of an adjudicator (Cheung, 1999).

Disputes reported in case study A generally concerned poor transparency, unreasonable programmes, stakeholder pressures, lack of involvement and ambiguous information. As most of the disputes reported in case study A reflect higher levels of cognition than interest, the focus of resolving these were more on determining the truth. Disputes reported in case study B primarily concerned threatening behaviours and contract variation claims. As most of the disputes reported in case study B generally reflect high levels of cognition and interest, the foci of resolving these were on determining both justice and truth. Disputes reported in case study $\mathrm{C}$ generally concerned the competitive tendering process, conflicting interests, scope of work, insufficient contract sum, deferring payments, performance issues and unsatisfactory outcomes. In contrast to case study A, as most of the disputes reported in case study $\mathrm{C}$ reflect higher levels of interest than cognition, the focus of resolving these was more on determining justice (Thibaut and Walker, 1978).

\subsection{Differences between case study project participants}

The solicitor involved in case study A believed stakeholder interactivity within this particular project to be generally harmonious due to the contractual arrangements that were initially administered. Contrasting viewpoints were expressed in their own ways by the government project client's executive manager, contractor's project engineer and adjudicator involved. Their expressions may reflect the timing of their involvement in this project when they experienced more onerous contractual responsibilities and adversarial disputes.

There was also some disagreement expressed by both a representative of the architect and contract manager of the contractor in case study B. The former warned that the SA caused their client a financial loss as this implemented a mechanism of paying first, then arguing about it later on. The latter emphasised that SA decisions were not final. Despite regarding his experience as effective, it was for these reasons that one of the lawyers involved described the SA as

[q]uick, high pressured and risky. (lawyer in case study B)

A representative of the architect and contract manager of the contractor both expressed that their parties will welcome the inclusion of the DB as a standard feature in their contracts within case study B. The lawyers involved in this particular infrastructure project were less convinced about the prospect of including the DB within the contracts as standard, primarily because they believed that it better suited larger megaprojects, such as the mining infrastructure development in case study C. There were other barriers encountered in implementing ADR methods, including the following

n inadequate education about the ADR method (lawyer in case study C)

- resistance to change (project engineer of the contractor in case study A)

- agreement among project stakeholders (government project client executive manager and adjudicator in case study A, architect representative in case study $\mathrm{B}$ and adjudicator in case study $\mathrm{C}$ )

- procedural compliance (solicitor in case study A, contract manager of the contractor in case study $\mathrm{B}$ and adjudicator in case study C)

- costly and lack of confidence in decisions that were not binding (lawyers in case study B and DB member and adjudicator in case study $\mathrm{C}$ ).

\subsection{Similarities between case study project participants}

The DB had been regularly active in facilitating the progress of case study C. Members of the DB involved determined that stakeholder interactions in this engineering infrastructure 
development were generally harmonious. They also emphasised that the DB was suited for uniquely documented projects and should have therefore been a standard feature of contracts in case study $\mathrm{C}$ to help its stakeholders better understand their risks when needed. This is because it was cost-effective in dispute resolution between stakeholders and maintaining their working relationships, relative to other projects. One member elaborated the following.

When subcontractors are required to do more than they bargained for, there is a natural tendency to try and find issues to dispute, which may result in additional cost recovery. (DB member in case study $\mathrm{C}$ )

The informal recommendations provided by the DB were satisfactory to all the project stakeholders (CIArb-Australia, 2016). The lawyer involved in case study $C$ was also satisfied with the effectiveness of DB outcomes. He also believed that the DB should have been a standard feature of contracts. The contract manager of the contractor and adjudicator involved both believed that their interactions with other project stakeholders relied on factors such as personality, motivation and stress, with the former describing the construction industry as

[b]umper to bumper ... We [the contractor] keep pushing people [their subcontractors] to perform [construction work] better and faster.

(contract manager of the contractor in case study C)

The project engineer of the contractor and solicitor involved in case study A both vouched that the SA was effective in achieving its objectives as well. The chartered surveyor involved regarded his SA experience as beneficial. Despite his positive SA experience, the chartered surveyor involved actually found the entire dispute-resolution process costly to his consultancy practice. Project stakeholders in general usually regarded each of their SA experiences as quite a frustrating and stressful disputeresolution process that was unsatisfactory to them. Both the government project client executive manager and solicitor involved in case study A found that the SA still resulted in costly litigation because of arbitrary decisions initially made by the adjudicator. It was primarily for these reasons that the government project client executive manager, as well as an end user company director, respectively, regarded the SA experience by itself as

[f]ast and cheap (government project client executive manager in case study A)

but

[q]uite painful. (end user company director in case study A)

\subsection{Factors influencing alternative dispute-resolution method selection}

The chartered surveyor involved and an end user company director, in making the following comments, both understood that stakeholder interactions had deteriorated as case study A progressed.
Tension between [case study A project] parties typically occurs when there is a lack of transparency in the [design, construction and demolition] processes and unreasonable programmes. (chartered surveyor in case study A)

[Case study A project] client pressure forces the head contractor, who in turn passes it onto the subcontractors ... Unrealistic programmes are probably the most common issue. (end user company director in case study A)

The adjudicator in case study A involved reported that SA applications increased gradually throughout this project. He further purported that the SA was a cost-effective ADR method in pursuing arbitration and litigation. The general consensus among the lawyers involved in case study B regarding SA was its cost-effectiveness as an ADR method from arbitration and litigation in resolving issues with payments. The reason they provided was that several orders to pay unpaid claims straight away were made by the SA in accordance with the Construction Contracts Act 2004 (Government of Western Australia, 2004). To prevent the costs encountered in case study A, the chartered surveyor involved preferred that the other party validate their claim with sufficient evidence before applying for SA. According to the contract manager of the contractor in case study B, their interactions with other project stakeholders were dependent on the following influences

[t] he economic climate ... [s]ize or type of project ... [h]ow the [construction] job was won, this builder's strategy and culture. (contract manager of the contractor in case study B)

\subsection{Similarities between dispute boards and statutory adjudication}

There was no real consensus among the stakeholders of case study A on DB effectiveness or whether it should have been a standard part of their contracts in this particular infrastructure project. For instance, the adjudicator involved believed that the standard inclusion of DB within the contract was not a good idea. The primarily reason for this belief, other than also operating within the legal industry, was because the adjudicator was naturally more in favour of the SA where their involvement remained for the entire project duration. Indeed, project stakeholders opined that the ADR objectives were to facilitate the following throughout the project

- dispute resolution if unable to contractually (architect representative and contract manager of the contractor in case study B)

- assessment fairness and reference to the Construction Contracts Act 2004 (Government of Western Australia, 2004: clause 30) (project engineer of the contractor in case study A and adjudicator in case study $\mathrm{C}$ )

- cost-effectively and quickly resolving disputes over payments (government project client executive manager, chartered surveyor, end user company director, adjudicator and solicitor in case study A and contract manager of the contractor and lawyers in case studies B and C). 
Both the lawyer and adjudicator involved in case study $\mathrm{C}$ emphasised that dispute resolution is normally more costly to a party when they are unhappy with the outcomes. Indeed, the contract manager of the contractor and the lawyer involved both found the entire dispute resolution process to be expensive because the ADR was part of a broader tactic which represented only its 'first round', and the adjudicator only determined the entitlement for payments without specifying a correct amount. For instance, the contractor sometimes submitted a progress claim that included a variation request to the project client. According to the Construction Contracts Act 2004 (Government of Western Australia, 2004), if the project client is late in certifying a progress claim, they are then required to pay the contractor in full regardless of its validity. These situations were summarised by the contract manager of the contractor as

[a] bit like this, pay [the contractor in full] now and argue [about all of the contract variation claims] later. (contract manager of the contractor in case study C)

\section{Discussion}

Determining an appropriate method of dispute resolution for a construction/engineering project had required further data to be gathered from its industry practitioners (Coggins et al., 2010). Some harmonious stakeholder interactions had been experienced by participants of the research presented in this paper within each case study project. Despite this harmony, this research was able to achieve its objectives. This research has advanced the current understanding of why, as well as how, the methods of DB and SA are being used to determine either justice or truth. These findings may lead to a greater understanding on which of these ADR methods are better suited for resolving disputes with certain characteristics in the construction industry. The implications presented by this research are that DB and SA could be embedded into standard forms of construction contracts so as no longer to exist as alternate methods of dispute resolution. It was also found that the choice of dispute-resolution method is based on the preference either to negotiate or to refer the decision on to a third party. This means that construction projects could formulate their conflict-management mechanism to adopt these methods for resolving justice- or truth-based disputes. It also means that the effective use of DB and SA in construction projects still has the potential of preventing more disputes from escalating to litigation.

\subsection{Need for alternate methods of dispute resolution} The main reason expressed by the majority of research participants for the need for ADR was summarised by the adjudicator involved in case study A. In making the following statement, he suggested that disputes fundamentally arise from the way contracts are written for use within these projects.

Construction contracts are typically set up in an adversarial manner. (adjudicator in case study A)

Consistent with the Dispute Resolution Board Foundation (DRBF, 2016), construction industry practitioners were found to be generally deficient in both their education about and experiences of DBs. Establishing the need for ADR in a construction and engineering project is significant as its contracts typically contain clauses that create adversity between parties.

\subsection{Barriers in dispute board implementation}

Barriers identified by Harmon (2009) hindering the effectiveness of a DB comprised its perception as adversarial, lengthy procedure, dubious recommendations and lower rate of dispute settlement. The most significant barriers of implementing DBs encountered by research participants were found to be relatively more fundamental. These were costliness, inadequate education, resistance to change, procedural compliance, reaching agreement among project stakeholders and lack of confidence in decisions that were not binding. There was a general consensus among the research participants that DBs were better suited for larger-scale megaprojects. These perceived barriers of DB implementation on a construction and engineering project are significant as they indicate significant deficiencies in the general understanding of DBs.

\subsection{Statutory adjudication experiences and effectiveness}

Practitioners in the legal industry - that is, DB members, adjudicators and lawyers - unanimously agreed about the effectiveness of SA in resolving disputes. According to the Construction Contracts Act 2004 (Government of Western Australia, 2004: clause 30), adjudicating a dispute over payment should be resolved informally, fairly, inexpensively and quickly. This is consistent with the general understanding of SA objectives perceived by and shared among the research participants. Despite sharing this general understanding, the research participants also expressed concerns about their SA experiences. Adjectives they used in describing these experiences included 'subjective', 'frustrating' and 'painful'. Most of these concerns primarily related to the quality of the adjudicator involved and their inconsistent decisions. They also support the regularity of SA errors recently reported by Skaik et al. (2016).

While effective in generally being quick, both the government project client executive manager and a chartered surveyor believed that these benefits also indirectly encouraged more claims for payment in case study A. For instance, the contractor of case study $\mathrm{C}$ was reported to go into administration soon after receiving several SA-authorised dubious payments, but before the project client had a chance of recovering them by litigation. This was in strong contrast to the low appeal and fairness of the SA purported by Brand and Davenport (2011), as well as by Yung and Rafferty (2014). Litigation by parties dissatisfied after the SA was a frequent occurrence; these parties then found their overall dispute-resolution experiences substantially more costly. This contradicted the notion that parties seldom pursue arbitration/ litigation after SA (Brand and Davenport, 2011).

These SA experiences, as well as perceptions of its effectiveness in construction, are significant as they raised issues of 
subjectivity, frustration, stress, pain and dissatisfaction with this particular ADR. The findings of this research expanded on the previous work of Yung and Rafferty (2014), through its additional focus on the effectiveness of DBs from the perspectives of a broader range of construction industry practitioners.

\section{Conclusion}

The research presented in this paper has identified requirements for ADR in the construction industry. The research participants were clearly dissatisfied with SA. Harmon (2009) has previously found some barriers in the use of DBs on one case study construction project in the USA. Barriers in implementing DBs on three case study construction/engineering projects were found in this research. These barriers indicate significant deficiencies in the general understanding of DBs. From this research, there remains no clear consensus among practitioners in the construction industry on DB effectiveness.

Their main focus should generally be on the prevention of disputes and minimising their associated cost when they occur. Previous researchers of related studies have primarily focused on perspectives of adjudicators. The value of this research is in its case studies of a holistic diversity of practitioners in the construction industry. Research participants are generally dissatisfied with SA as an ADR. This is in contrast with the notion of SA being a cost-effective and quick way to achieve the fair resolution of disputes previously advocated.

\section{REFERENCES}

ABS (Australian Bureau of Statistics) (2017) Australian Bureau of Statistics. Australian Government, Canberra, Australia. See http:// www.abs.gov.au/ (accessed 27/05/2017).

Agdas D and Ellis RD (2013) Analysis of construction dispute review boards. Journal of Legal Affairs and Dispute Resolution in Engineering and Construction 5(3): 122-127, https://doi.org/10.1061/ (ASCE)LA.1943-4170.0000118.

Aibinu AA (2006) The relationship between distribution of control, fairness and potential for dispute in the claims handling process. Construction Management and Economics 24(1): 45-54, https://doi. org/10.1080/14697010500226954.

Aibinu AA, Ofori G and Ling FYY (2008) Explaining cooperative behaviour in building and civil engineering projects' claims process interactive effects of outcome favourability and procedural fairness Journal of Construction Engineering and Management 134(9): 681-691, https://doi.org/10.1061/(ASCE)0733-9364(2008)134:9(681).

Aibinu AA, Ling FYY and Ofori G (2011) Structural equation modelling of organizational justice and cooperative behaviour in the construction project claims process - contractors' perspectives. Construction Management and Economics 29(5): 463-481, https://doi.org/10.1080/ 01446193.2011 .564195 .

Brand MC and Davenport P (2011) Proposal for a 'dual scheme' model of statutory adjudication for the Australian building and construction industry. International Journal of Law in the Built Environment 3(3): 252-268, https://doi.org/10.1108/17561451111178452.

Brand MC and Davenport P (2012) Adjudication in Australia - an analysis of the amendments introduced by the Building and Construction Industry Security of Payment Amendment Act 2010 (NSW). International Journal of Law in the Built Environment 4(3): 189-202, https://doi.org/10.1108/17561451211273347.
Chapman PHJ (2009) Dispute boards on major infrastructure projects. Proceedings of the ICE - Management, Procurement and Law 162(1): 7-16, https://doi.org/10.1680/mpal.2009.162.1.7.

Cheung SO (1999) Critical factors affecting the use of alternative dispute resolution processes in construction. International Journal of Project Management 17(3): 189-194, https://doi.org/10.1016/S0263-7863(98) 00027-1.

CIArb-Australia (Chartered Instituted of Arbitrators-Australia) (2016) An Introduction to Dispute Boards. CIArb-Australia, Sydney, Australia. See https://www.ciarb.net.au/resources/dispute-boards/anintroduction-to-dispute-boards/10.1680/mpal.2009.162.1.7 (accessed 27/05/2017).

Coggins J, Elliott RF and Bell M (2010) Towards harmonisation of construction industry payment legislation - a consideration of the success afforded by the east and west coast models in Australia. Australasian Journal of Construction Economics and Building 10(3): 14-35, https:// doi.org/10.5130/AJCEB.v10i3.1804.

Cole TRH (2003) Final Report of the Royal Commission into the Building and Construction Industry, Volume 8 Reform - National Issues Part, vol. 2. Australian Government, Canberra, Australia.

CRC-Construction Innovation (Cooperative Research Centre-Construction Innovation) (2009) Guide to Leading Practice for Dispute Avoidance and Resolution. CRC, Brisbane, Australia.

Davenport P (2010) Adjudication in the Building Industry, 3rd edn. Federation Press, Annandale, Australia.

Drake Quantity Surveying (2013) Dispute Resolution in Construction Getting It Right First Time. Drake Quantity Surveying, Manchester, UK. See http://www.drakeqs.co.uk/blog/dispute-resolution-inconstruction-getting-it-right-first-time./\#sthash.qxlopz8V.dpuf (accessed 19/11/2017).

DRBF (Dispute Resolution Board Foundation) (2016) The Dispute Resolution Board Foundation. DRBF, Charlotte, NC, USA. See http:// www.drbf.org.au/ (accessed 01/09/2016).

Fellows R and Liu A (2008) Research Methods for Construction, 3rd edn. Wiley-Blackwell, Oxford, UK.

FHWA (Federal Highway Administration) (2017) Megaprojects - They Are A Different Breed. FHWA, Washington, DC, USA. See https://www. fhwa.dot.gov/publications/04jul/01.cfm (accessed 27/05/2017).

Fidic (International Federation of Consulting Engineers) (2017) The Global Voice of Consulting Engineers. Fidic, Geneva, Switzerland. See http://www/fidic.org (accessed 19/11/2017).

Gebken-Li R and Gibson G (2006) Quantification of costs for dispute resolution procedures in the construction industry. Journal of Professional Issues in Engineering Education and Practice 132(3): 264-271, https://doi.org/10.1061/(ASCE)1052-3928(2006)132:3(264).

Government of Western Australia (2004) Construction Contracts Act 2004. Act No. 16 of 2004. Government of Western Australia, Perth, WA, Australia. See http://www7.austlii.edu.au/cgi-bin/viewdb/au/legis/ wa/consol_act/cca2004284/ (accessed 01/09/2016).

Hall R (2008) Applied Social Research - Planning, Designing and Conducting Real World Research. Palgrave Macmillan, Melbourne, Australia.

Harmon K (2003a) Resolution of construction disputes - a review of current methodologies. Leadership and Management in Engineering 3(4): 187-201, https://doi.org/10.1061/(ASCE)1532-6748(2003)3:4 (187).

Harmon K (2003b) Effectiveness of dispute review boards. Journal of Construction Engineering and Management 129(6): 674-679, https:// doi.org/10.1061/(ASCE)0733-9364(2003)129:6.

Harmon K (2009) Case study as to the effectiveness of dispute review boards on the central artery/tunnel project. Journal of Legal Affairs and Dispute Resolution in Engineering and Construction 1(1): 18-31, https://doi.org/10.1061/(ASCE)1943-4162(2009)1:1(18).

Harmon K (2012) Using DRBs to maintain control of large, complex construction projects. Dispute Resolution Journal 67(1): 70-75. 
ICC-WBO (International Chamber of Commerce-World Business Organization) (2017) We Are the World Business Organization. ICC, Paris, France. See https://iccwbo.org/ (accessed 19/11/2017).

LinkedIn (2017) https://au.linkedin.com (accessed 27/05/2017). Love PED, Davis PR, Ellis J and Cheung SO (2010) Dispute causation identification of pathogenic influences in construction. Engineering Construction and Architectural Management 17(4): 404-423, https:// doi.org/10.1108/09699981011056592.

Love PED, Davis PR, Cheung SO and Irani Z (2011) Causal discovery and inference of project disputes. IEEE Transactions on Engineering Management 58(3): 400-411, https://doi.org/10.1109/TEM.2010. 2048907.

Murphy SE, Spillane JP, Hendron C and Bruen J (2014) NEC contracting evaluation of the inclusion of dispute review boards in lieu of adjudication in the construction industry in the United Kingdom. Journal of Legal Affairs and Dispute Resolution in Engineering and Construction 6(4): 04514002, https://doi.org/10.1061/(ASCE)LA. 1943-4170.0000147.

NSW Government (1999) Building and Construction Industry Security of Payment Act 1999. Act No. 46 of 1999. New South Wales Government, Sydney, NSW, Australia. See http://www.austlii.edu.au/ au/legis/nsw/consol act/bacisopa1999606/ (accessed 01/09/2016).

NSW Government (2010) Building and Construction Industry Security of Payment Amendment Act 2010. Act No. 103 of 2010. New South Wales Government, Sydney, NSW, Australia.

Partington M (2017) Introduction to the English Legal System. Oxford University Press, Oxford, UK.

QSR International (2017) NVivo - the \#1 Software for Qualitative Dato Analysis. QSR International, Doncaster, Australia. See http://www. qsrinternational.com/nvivo-product (accessed 02/03/2017).

Robson C (2011) Real World Research - a Resource for Users of Social Research Methods in Applied Settings. Wiley, West Sussex, UK.

Ross S (2013) Security of payment legislation in Australia - issues with adjudication decisions. Journal of New Business Ideas and Trends 11(1): 47-53.

Salmon B (2015) Recording disclosure - getting it right first time. Corporate Disputes Magazine, January-March: p. 22. See https://www.corporatedisputesmagazine.com/recording-disclosuregetting-it-right-first-time/ (accessed 19/11/2017).

Skaik S, Coggins J and Mills A (2016) Australian security of payment legislation - impact of inconsistent case law. Proceedings of the 40th Australasian Universities Building Education Association (AUBEA) Conference, Cairns, Australia, pp. 671-681.

Thibaut J and Walker L (1978) A theory of procedure. California Law Review 66(3): 541-566.

Williamson OE (1975) Markets and Hierarchies - Analysis and Antitrust Implications - A Study in the Economics of Internal Organization. University of Illinois-Champaign's Academy for Entrepreneurial Leadership Historical Research Reference in Entrepreneurship, Urbana, IL, USA. See https://ssrn.com/abstract=1496220 (accessed 19/ 11/2017).

Williamson OE (1979) Williamson on predatory pricing II. Yale Law Journal 88(6): 1183-1201, https://doi.org/10.2307/795627.

Williamson OE (1980) The organization of work - a comparative institutional assessment. Journal of Economic Behavior and Organization 1(1): 5-38, https://doi.org/10.1016/0167-2681(80)90050-5.

Wong PSP, Wang ZH and Do D (2015) Use of the Security of Payment Act in resolving disputes in Victoria, Australia. Journal of Legal Affairs and Dispute Resolution in Engineering and Construction 7(1): A4514001, https://doi.org/10.1061/(ASCE)LA.1943-4170. 0000148 .

World Bank (2017) 15 Years of Reforms to Improve Business Climate Worldwide. World Bank Group, Washington, DC, USA. See http:// www.worldbank.org (accessed 19/11/2017).

XE.com (2017) http://www.xe.com/currencyconverter (accessed 08/06/2017).

Yates J and Duran J (2006) Utilizing dispute review boards in relational contracting - a case study. Journal of Professional Issues in Engineering Education and Practice 132(4): 334-341, https://doi.org/ 10.1061/(ASCE)1052-3928(2006)132:4(334).

Yung P and Rafferty K (2014) Statutory adjudication in Western Australia - adjudicator's views. Engineering, Construction and Architectural Management 22(1): 54-72, https://doi.org/10.1108/ ECAM-03-2014-0033.

\section{How can you contribute?}

To discuss this paper, please email up to 500 words to the editor at journals@ice.org.uk. Your contribution will be forwarded to the author(s) for a reply and, if considered appropriate by the editorial board, it will be published as discussion in a future issue of the journal.

Proceedings journals rely entirely on contributions from the civil engineering profession (and allied disciplines). Information about how to submit your paper online is available at www.icevirtuallibrary.com/page/authors, where you will also find detailed author guidelines. 